\title{
Prevalence and determinants of nonadherence to highly active antiretroviral therapy among people living with HIV/AIDS in Ibadan, Nigeria
}

\author{
Samuel A. Olowookere ${ }^{1}$, Akinola A. Fatiregun ${ }^{2}$, Joshua O. Akinyemi ${ }^{2}$, \\ Afolabi E. Bamgboye ${ }^{2}$, Gordon K. Osagbemi ${ }^{3}$ \\ ${ }^{1}$ Department of Medicine, State Hospital, P.O. Box 1203, Osogbo, or PMB 4307, Asubiaro, Osogbo, Nigeria \\ ${ }^{2}$ Department of Epidemiology, Medical Statistics and Environmental Health, Faculty of Public Health, College of Medicine, \\ University of Ibadan, Ibadan, Nigeria \\ ${ }^{3}$ Department of Epidemiology and Community Health, College of Health Sciences, University of Ilorin, Ilorin, Nigeria
}

\begin{abstract}
Objective: To determine the level of nonadherence to highly active antiretroviral therapy (HAART) and to explore the association of factors militating against adherence and nonadherence to therapy among people living with HIV/AIDS (PLWHA) at an Antiretroviral Clinic in Ibadan, Nigeria.

Design: A cross-sectional survey was employed to determine the prevalence of nonadherence.

Methodology: A structured interviewer-administered questionnaire was applied to consecutive PLWHA who had been on therapy for a minimum of three months. The completed questionnaires were entered into a computer and analyzed. Multivariate logistic regression was used to determine factors associated with nonadherence.

Results: Three hundred and eighteen people living with HIV/AIDS completed the questionnaire. Their mean age was $39.1 \pm 9.6$ years. There were $173(54.4 \%)$ females and $145(45.6 \%)$ males. The median duration on HAART was 19 months (Range 3 to 28 months) and the prevalence of nonadherence was $118(37.1 \%)$ using the less than 95\% adherence profile. About a third (31.5\%) of those missing therapy reportedly missed their medication because of fasting. Multiple logistic regression analysis revealed that patients who felt healthy or simply forgot to take their drugs and those not willing to disclose their HIV status were independently, significantly associated with less than 95\% adherence.

Conclusion: The study showed that nonadherence to HAART is a problem in the ARV clinic and that the feeling of being healthy, forgetfulness, and unwillingness to disclose HIV status by PLWHA were significant barriers to adherence. Efforts to improve adherence in the clinic will have to address these issues among others.
\end{abstract}

Key Words: nonadherence, antiretroviral therapy, HIV/AIDS

J Infect Developing Countries 2008; 2(5):369-372.

Received 12 November 2007 - Accepted 22 July 2008

Copyright () 2007 Olowookere et al. This is an open access article distributed under the Creative Commons Attribution License, which permits unrestricted use, distribution, and reproduction in any medium, provided the original work is properly cited.

\section{Introduction}

The Human Immunodeficiency Virus/Acquired Immune Deficiency Syndrome (HIV/AIDS) has spread to all the regions of the world with a most devastating effect in sub-Saharan Africa [1]. The first case of AIDS in Nigeria was reported in 1986 [2,3]. Since then the prevalence of HIV infection in pregnant women increased from $1.8 \%$ in 1991 to $5.4 \%$ in 1999 . A slight decline to $5.0 \%$ was observed in 2003 [3]. Nationally, about $4.4 \%$ of women attending antenatal clinics were found to be infected with HIV in 2005, but prevalence among pregnant women exceeded $5 \%$ in almost a third of the 36 states in the country [3].

Highly active antiretroviral therapy (HAART) is the only proven treatment for HIV/AIDS. HAART is the combination of three or more drugs from at least two different classes of antiretroviral (ARV) therapy. A key determinant of successful HAART is drug adherence. Poor adherence can lead to treatment failure, evolution of drug resistance, and subsequent immunological and clinical failure [4]. More than $95 \%$ of the doses should be taken for optimal response while lesser degrees of adherence are more often associated with virological failure. Various studies have documented that the range for adherence to HAART is from $25 \%$ to $85 \%$ [5]. Adherent individuals have been shown to have reduced viral loads and increased CD4 counts, live longer, and have better quality of life $[4,6,7]$.

Since the Antiretroviral Clinic, University College Hospital, started to prescribe and dispense the HAART 
regimen to people living with HIV/AIDS (PLWHA) in 2004, the level of adherence to HAART and likely factors militating against good adherence to the HAART regimen had not been assessed among the clinic attendees. This assessment, however, is necessary for evaluating the antiretroviral treatment program and for finding solutions to identified barriers to adherence in order to prevent treatment failure and the development of drug resistance among these patients.

\section{Materials and Methods}

The study was conducted at the Antiretroviral Clinic of the University College Hospital (an 850-bed tertiary hospital), Ibadan, Nigeria. The ARV clinic was one of 25 other ARV clinics established and funded by the Federal Government in 2002 to provide Antiretroviral drugs to an initial 10,000 adults nationwide at a subsidized rate. Since 2004, President Bush's Emergency Plan for AIDS Relief (PEPFAR) had provided immense support for the scale-up of the nation's antiretroviral treatment programme initially at the government subsidized rate of 1,000 Naira per month (\$7.0) but free since January, 2006. The ARV Clinic opens daily from 8:00 a.m. to 5:00 p.m. Monday through Thursday. The clinic serves the entire southwestern part of Nigeria and beyond.

A descriptive cross-sectional study aimed at documenting the level of nonadherence among patients living with HIV/AIDS who had been on HAART for at least three months in the clinic was conductedbetween June and August 2007. Consecutive patients were recruited into the study after consent. A pretested interviewer administered a questionnaire that was completed by each study participant with the assistance of the investigators. Clinical checklist data was obtained from the respondent's clinic records. This included comorbidity history, CD4 count, and viral load of each study participant at baseline and at three months.

Degree of adherence by individual patients was estimated manually by means of drug pickup by patients at the clinic pharmacy and by patient selfreport. The degree of adherence from patient self-report [8] was estimated using the following formula:

$\%$ Adherence over last 7 days $=\frac{\# \text { doses should have taken }-\# \text { missed doses }}{\# \text { doses should have taken }} \times 100 \%$

From the formula, level of adherence by individual patients was classified into those with less than $95 \%$ adherence and those with equal to or more than $95 \%$ adherence. Nonadherent patients were defined in this study as individuals with less than $95 \%$ adherence level.
The prevalence of nonadherence was estimated for those who ever missed and those who missed more than $5 \%$ of their medication.

The data were entered into a computer, cleaned, and statistical analysis was performed using Statistical Package for Social Sciences SPSS version 12. Tables of frequency were generated, and tests of significance were conducted using appropriate statistical methods. Multivariate analysis was performed using logistic regression to evaluate the socio-demographic variables and other variables that were independently associated with nonadherence.

Informed consent was obtained from all respondents while, permission to conduct the study was sought from the ARV clinic research committee. Serial numbers and not names were used to maintain confidentiality.

\section{Results}

Three hundred and eighteen people living with HIV/AIDS on HAART participated in the study. The mean age of respondents was 39.1 years $(\mathrm{SD} \pm 9.6)$. The largest proportion of the PLWHA $(130 ; 40.9 \%)$ were in the age group of 30 to 39 years, followed by 93 (29.2\%) in the 40 to 49 years age group. The majority of those interviewed $(173 ; 54.4 \%)$ were females; $145(45.6 \%)$ were males; $131(41.2 \%)$ were traders; and $251(78.9 \%)$ were of the Yoruba tribe. About half, 144 (45.3\%), of the study population had secondary education while 103 $(32.4 \%)$ had tertiary education. The majority of the study population $(212 ;(66.7 \%)$ were married at the time of interview (Table 1).

Table 2 shows the distribution of respondents by month on highly active antiretroviral therapy. Over half of the study population had been on HAART for 18 months and above. The median duration on HAART was 19.0 months (range 3-28 months). Table 3 shows the prevalence of nonadherence to HAART. One hundred and eighteen respondents $(37.1 \%)$ had less than 95\% adherence, while 216 (67.9\%) had ever missed their medication. Table 4 shows reasons for missing medication. One hundred and twenty (55.6\%) study participants who ever missed their medication reported that they simply forgot to take their medication and 68 $(31.5 \%)$ stated fasting as the reason for missing medication. Fifty-seven (26.4\%) missed their drugs because they felt they were now well and hence no longer needed to take their medication again. Also 76 (35.2\%) missed taking their drugs because they wanted to avoid side effects/toxicities of the drugs. Common side effects/toxicities reported included nausea/ 
vomiting (19.5\%), skin rash (15.7\%), diarrhoea $(23.9 \%)$, dizziness $(13.8 \%)$, paresthesia $(11.9 \%)$ and bad dreams $(14.5 \%)$.

Table 1. Demographic characteristics of PLWHA respondents.

\begin{tabular}{|c|c|c|c|c|}
\hline $\begin{array}{l}\text { Demographic } \\
\text { characteristics }\end{array}$ & $\begin{array}{r}\text { Sex } \\
\text { Male } n=145\end{array}$ & Female $n=173$ & Total $n=318$ & *p value \\
\hline $\begin{array}{l}\text { Age group } \\
15-19 \\
20-29 \\
30-39 \\
40-49 \\
50 \text { and above } \\
\text { mean age } \\
\text { age range }\end{array}$ & $\begin{array}{l}1(0.7 \%) \\
9(6.2 \%) \\
54(37.2 \%) \\
46(31.7 \%) \\
35(24.1 \%) \\
41.8 \pm 9.4 \text { years } \\
14-64 \text { years }\end{array}$ & $\begin{array}{l}2(1.2 \%) \\
33(19.1 \%) \\
76(43.9 \%) \\
47(27.2 \%) \\
15(8.7 \%) \\
36.8 \pm 9.1 \text { years } \\
14-60 \text { years }\end{array}$ & $\begin{array}{l}3(0.9 \%) \\
42(13.2 \%) \\
130(40.9 \%) \\
93(29.2 \%) \\
50(15.7 \%)\end{array}$ & $\mathrm{p}=0.000$ \\
\hline $\begin{array}{l}\text { Level of education } \\
\text { None } \\
\text { Primary school } \\
\text { Secondary school } \\
\text { Tertiary school }\end{array}$ & $\begin{array}{l}6(4.1 \%) \\
25(17.2 \%) \\
65(44.8 \%) \\
49(33.8 \%)\end{array}$ & $\begin{array}{l}9(5.2 \%) \\
31(17.9 \%) \\
79(45.7 \%) \\
54(31.2 \%)\end{array}$ & $\begin{array}{l}15(4.7 \%) \\
56(17.6 \%) \\
144(45.3 \%) \\
103(32.4 \%)\end{array}$ & $\mathrm{p}=0.943$ \\
\hline $\begin{array}{l}\text { Marital status } \\
\text { Single } \\
\text { Married } \\
\text { Divorced } \\
\text { Widowed }\end{array}$ & $\begin{array}{l}17(11.7 \%) \\
113(77.9 \%) \\
8(5.5 \%) \\
7(4.8 \%)\end{array}$ & $\begin{array}{l}26(15.0 \%) \\
99(57.2 \%) \\
23(13.3 \%) \\
25(14.5 \%)\end{array}$ & $\begin{array}{l}43(13.5 \%) \\
212(66.7 \%) \\
31(9.7 \%) \\
32(10.1 \%)\end{array}$ & $\mathrm{p}=0.000$ \\
\hline $\begin{array}{l}\text { Ethnic group } \\
\text { Yoruba } \\
\text { Ibo } \\
\text { Hausa } \\
\text { Others }\end{array}$ & $\begin{array}{l}112(77.2 \%) \\
14(9.7 \%) \\
6(4.1 \%) \\
13(9.0 \%)\end{array}$ & $\begin{array}{c}139(80.3 \%) \\
14(8.1 \%) \\
6(3.5 \%) \\
14(8.1 \%)\end{array}$ & $\begin{array}{l}251(78.9 \%) \\
28(8.8 \%) \\
12(3.8 \%) \\
27(8.5 \%)\end{array}$ & $\mathrm{p}=0.923$ \\
\hline $\begin{array}{l}\text { Occupation } \\
\text { Civil servant } \\
\text { Artisan } \\
\text { Trader } \\
\text { Soldier/police } \\
\text { Unemployed }\end{array}$ & $\begin{array}{l}42(29.0 \%) \\
27(18.6 \%) \\
49(33.8 \%) \\
18(12.4 \%) \\
9(6.2 \%)\end{array}$ & $\begin{array}{l}53(30.6 \%) \\
15(8.7 \%) \\
82(47.4 \%) \\
2(1.2 \%) \\
21(12.1 \%)\end{array}$ & $\begin{array}{l}95(29.9 \%) \\
42(13.2 \%) \\
131(41.2 \%) \\
20(6.3 \%) \\
30(9.4 \%)\end{array}$ & $\mathrm{p}=0.000$ \\
\hline $\begin{array}{l}\text { Income } \\
\text { Less than N4500 } \\
4500 \text { and above }\end{array}$ & $\begin{array}{l}39(26.9 \%) \\
106(73.1 \%)\end{array}$ & $\begin{array}{l}97(56.1 \%) \\
76(43.9 \%)\end{array}$ & $\begin{array}{l}136(42.8 \%) \\
182(57.2 \%)\end{array}$ & $\mathrm{p}=0.000$ \\
\hline $\begin{array}{l}\text { Residence lived } \\
\text { Ibadan } \\
\text { Outside Ibadan }\end{array}$ & $\begin{array}{l}77(53.1 \%) \\
68(46.9 \%)\end{array}$ & $\begin{array}{l}98(56.6 \%) \\
75(43.4 \%)\end{array}$ & $\begin{array}{l}175(55.0 \%) \\
143(45.0 \%)\end{array}$ & $\mathrm{p}=0.527$ \\
\hline
\end{tabular}

Table 2. Distribution of PLHWA by month on HAART.

\begin{tabular}{lll}
\hline Duration (month) & Frequency & \% \\
\hline $3-5$ & 26 & 8.2 \\
$6-11$ & 74 & 23.3 \\
$12-17$ & 57 & 17.9 \\
$18-23$ & 76 & 23.9 \\
24 months and above & 85 & 26.7 \\
Total & 318 & 100.0 \\
\hline
\end{tabular}

Table 3. Prevalence of non-adherence to highly active antiretroviral therapy.

\begin{tabular}{lll}
\hline Level of adherence & Frequency & $\%$ \\
\hline$<95.0 \%$ & 118 & 37.1 \\
$\geq 95.0 \%$ & 200 & 62.9 \\
Ever missed & 216 & 67.9 \\
Never missed & 102 & 32.1 \\
\hline Total & 318 & 100.0 \\
\hline
\end{tabular}

However, multiple logistic regression analysis (Table 5) shows that patients who felt healthy, those who simply forgot to take their drugs, and those not willing to disclose their HIV status were independently more likely to have less than $95 \%$ adherence level. A Hosmer and Lemeshow goodness of fit test resulted in a $\mathrm{p}=0.103$ and an adjusted $\mathrm{R}^{2}$ of 0.137 , indicating a fair fit of the model.
Table 4. Reasons for missing HAART by PLWHA who ever missed therapy.

\begin{tabular}{lll}
\hline Reason & $\begin{array}{l}\text { Frequency* } \\
\text { n=216 }\end{array}$ & \% \\
\hline Simply forgot & 120 & 55.6 \\
Wanted to avoid side effects & 76 & 35.2 \\
Were away from home & 72 & 33.3 \\
Lived too far away & 70 & 32.4 \\
Was fasting & 68 & 31.5 \\
Fell asleep/slept through dose time & 58 & 26.9 \\
Felt good/well & 57 & 26.4 \\
Ran out of pills & 54 & 25.0 \\
Unable to pay for transport & 54 & 25.0 \\
Do not like taking drugs & 50 & 23.1 \\
Did not want others to notice you taking medication & 45 & 20.8 \\
Felt depressed/sad/unhappy & 43 & 19.9 \\
Doubt that medication will work & 28 & 13.0 \\
Felt sick or ill & 26 & 12.0 \\
Had too many pills/tablet to take & 25 & 11.6 \\
Afraid of taking medication & 19 & 8.8 \\
Shared pills with others & 16 & 7.4 \\
\hline *Multiple responses are possible. & &
\end{tabular}

Table 5. Multiple logistic regression analysis of risk factors for less than $95 \%$ adherence.

\begin{tabular}{lllll}
\hline & & & \multicolumn{2}{c}{ 95\% CI } \\
\hline Independent Variable & P & $\begin{array}{l}\text { Odds } \\
\text { ratio }\end{array}$ & Lower & Upper \\
\hline Felt good/well & 0.005 & 2.39 & 1.3 & 4.4 \\
Unable to pay for transport & 0.06 & 1.83 & 0.98 & 3.4 \\
Were away from home & 0.59 & 1.76 & 0.98 & 3.2 \\
Simply forgot & 0.003 & 2.1 & 1.3 & 3.4 \\
Not willing to expose HIV status & 0.037 & 1.7 & 1.0 & 2.8 \\
\hline
\end{tabular}

\section{Discussion}

The level of nonadherence to HAART and its determinants among patients attending the Antiretroviral Clinic in Ibadan was the focus of this study. About two-fifths (37.1\%) of the respondents had less than $95 \%$ adherence. Various publications had shown that suboptimal adherence results in poor clinical response and thereby poor quality of life $[1,3,8]$. Our current findings show that nonadherence to HAART treatment is common among PLWHA in this centre and efforts should be made to reduce this problem. Emphasis has to be placed on $100 \%$ adherence during counseling sessions, though at least $95 \%$ adherence is required for optimal clinical response and complete viral suppression $[9,10]$.

Various studies on drug adherence reported that forgetting to take a dose and side effects/toxicities are major reasons that people missed their medication. For example, in a diverse sample of antiretroviral recipients, 29 poorly adherent patients listed a total of 50 reasons for not adhering to their therapy. Over half were related to side effects/toxicity and forgetfulness, $28 \%$ and $24 \%$ respectively $[11,12,13,14]$. This observation is consistent with the findings in this study, where the major reasons for missing therapy reported included 
forgetting to take drugs (55.6\%), and side effects/toxicities (35.2\%). Other reasons reported were living too far away (32.4\%), fasting (31.5\%), and the patients' feelings that they are well and therefore no longer need to take medication (26.4\%).

The observation that about a third $(31.5 \%)$ of nonadherence patients attributed their missing therapy to fasting is very instructive, especially in our environment where religious beliefs among muslims and Christians alike play an important role in determining health behaviour. Although Habib et al., (2008) reported in a study on adherence to anti retroviral therapy (ART) during muslim Ramadan fasting that adherence on ART was similar among fasting and non-fasting patients [15], our findings suggest the need to routinely consider patients who are fasting and advise them on what to do regarding the taking of their medications during a fast, or place them appropriately on an ART regimen that will not undermine their fast.

The multivariate logistic regression showed that those who felt good or well have a 2.4 fold risk of having less than $95 \%$ adherence to HAART, followed by those who simply forget to take medication (2.1 fold risk) and those with unwillingness to disclose their status (1.7 fold risk). These findings are supported by various studies which reported that forgetting to take a dose as the most commonly seen predictors of poor adherence to therapy $[12,16,17]$.

In conclusion, most PLWHA studied were in their prime and literate. The majority had been on HAART for more than 18 months. The study showed that nonadherence to HAART is a problem in the ARV clinic and that the feeling of being healthy, forgetfulness and unwillingness to disclose HIV status by PLWHA were significant barriers to adherence. Efforts to improve adherence in the clinic will have to address these issues among others.

\section{References}

1. UNAIDS/WHO (2006) AIDS epidemic update, December 2006. http://www.unaids.org accessed on 12th April, 2007

2. Federal Ministry of Health (FMOH), Department of Public Health (2002) HIV/AIDS: What It Mean for Nigeria Background, Projections, Impact, Intervention and Policy. The National AIDS and STD Control Programme, Abuja, Nigeria in collaboration with the National Action Committee on AIDS 110 .

3. Federal Ministry of Health (FMOH) (2005) Guideline for the use of ARV Drugs in Nigeria. Federal Ministry of Health, Abuja 24-45.

4. Machtinger EL, Bangsberg DR (2005) Adherence to HIV Antiretroviral Therapy. HIV InSite Knowledge Base Chapter. USA.
5. Bachiller P, Arrando FR, Liceaga G, Iribarren JA, Olloquiegui E, (1988) Adherence to antiretroviral therapy in HIV-infected persons. 12th World AIDS Conference. Geneva, [Abstract \#32392].

6. Richter A, Simpson KN, Manskopf JA (1998) Impact of drug non-compliance and the frequency of viral load testing on outcomes, costs and patterns of therapy. 12th World AIDS Conference. Geneva [Abstract \#42173].

7. LeMoing V, Masquelier B, Moatti JP, Journot V, Sicard D, (1999) To study predictors of immunologic response to PI therapy, along with virologic response, including adherence to therapy. 39th Interscience Conference on Antimicrobial Agents and Chemotherapy. San Francisco [Abstract \#596].

8. Horizons/Population Council (2004) Adherence to Antiretroviral Therapy in Adults. A Guide For Trainers.1-130.

9. Adeyi O, Kanki PJ, Odutolu O, Idoko JA (2006) AIDS in Nigeria. A nation on the threshold. Harvard Center for Population and Development Studies; 1st Ed. ; 385-428.

10. Paterson D. Swindells S, Mohr J, Brester M, Vergis E,(1999) How much adherence is enough? A prospective study of adherence to protease inhibitor therapy using MEMS caps. 6th conference on Retroviruses and Opportunistic Infections. Chicago [Abstract \# 92].

11. Websterb RD, Barr D (1999) Adherence to Highly Active Antiretroviral Therapy. A compendium of HAART Adherence Research, November 1997- November 1999; 2-17.

12. Weidle PJ, Ganea CE, Ernst J, McGowan J, Irwin KL, Holmberg SD (1998) Multiple reasons for non-adherence to antiretroviral medications in an inner-city minority population: Need for a multi-faceted approach to improve adherence. 12th World AIDS Conference. Geneva, [Abstract \#32375].

13. Murri R, Ammassari A, Gallicano K, DeLuca A, Cingolani A, (1999). Relationship of self reported adherence to HAART with protease inhibitor plasma level and viral load. 39th Interscience Conference on Antimicrobial Agents and Chemotherapy, San Francisco [Abstract \#593].

14. Nakashima AK, Jones JL, Burgess DA, Ward JW (1998) Adherence to currently prescribed antiretroviral therapies: Results from a multi-site interview project. 12th World AIDS Conference. Geneva[Abstract \#392/32326].

15. Habib AG, Shepherd JC, Eng MK, Babasani M, Jumare J (2008) Adherence to antiretroviral therapy during Muslim Ramadan fasting AIDS Behav.

16. Stone VE, Clark J, Lovell J, Steger KA, Hirschhorn LR (1998) HIV/AIDS patients' perspectives on adhering to regimens containing protease inhibitors. J Gen Intern Med. 13:586-593.

17. Brown MA, Inouye J, Powell-Cope GM, Holzemer WL, Nokes KM,(1998) Social support and adherence in HIV+ persons. 12th World AIDS Conference. Geneva,[Abstract \#32346].

Corresponding Author: AA Fatiregun, Department of Epidemiology, Medical Statistics and Environmental Health, Faculty of Public Health, College of Medicine, University of Ibadan, Ibadan, Nigeria

E-mail: akinfati@yahoo.com

Conflict of interest: No conflict of interest is declared. 